\title{
To my departed brother, Abbas Bahri, gone too soon
}

(C) The Author(s) 2017. This article is an open access publication

The world misses Abbas Bahri, a mathematician like no other, a Man of science and culture, a true scientist in the medieval sense of the word, an Erudite, and a universal spirit. He was undoubtedly the most powerful mind Tunisia that could have bred. I lost on January 10, 2016 a friend of 40 years, a companion through thick and thin, a true brother.

I met him in Paris in 1974, I had just arrived from Tunis at that time and Abbas had just joined the Ecole Normale Supérieure at Rue d'Ulm. Mathematics had brought us together and politics just as much. We were left-wing activists in a country that tolerated only a single political view/opinion, Patriots, and internationalists; together, we have crossed paths with the most consistent intellectual controversies of the era-within a small opposition party - that young people of our generation had been able to embrace.

Democracy vs. socialism was the most prominent polemic, the resolution of which paved the way to the long winding road to the 2011 Tunisian revolution. Islam vs. politics brought along by the Iranian revolution and the 'outbreak' of Islamism in the Tunisian political scene. I still have fond memories of our endless debates in the smoky student rooms that served as meeting places for our convergences and divergences, which unfailingly ended over a good meal. Those rants were tinged with a scholarly, well-reasoned substance so typical of Abbas: summoning the history of Tunisia from Al-Kahena to Ali Ben Ghedahem, that of the contemporary social and national movement, and the history of the world; Conjuring also the modern thought stemming from the Renaissance and the French Revolution nourished by elements of science and culture, many of which had drawn from the Arab-Islamic civilization's golden age.

Abbas was at the forefront of all discussions and debates. He was involved in the political arena, with the creation of the "Base des grandes écoles » which was the blueprint structure to ATUGE (Association des Tunisiens des Grandes Ecoles). He was an active figure in the Tunisian cultural landscape, with the launch of the Ibn El Haythem "cineclub", the organization of Tunisian Cultural Days, and the publishing of the movie magazine "Adhoua".

Not to mention, by the same token, his seasoned activism within the Student Union (UGET) and the Tunisian January 26th Forum, which was set up to defend the Tunisian General Labor Union (UGTT) which at that time, was up in arms over the regime repression. Memories are jostling now. In Paris metro, in the late 1970s, in the wee hours of the morning, we were busy putting up posters, dashing across platforms fleeing RATP security and police officers, the reward of which is a nice cup of black coffee from some nearby bistro that had just opened. Abbas, heavily smeared with glue, greeted us detachedly one of those mornings to go about quietly to take on the 'Aggregation' examination due in an hour time. He was admitted, of course, who ranked 25th out of about 200 accepted, in this contest which was then of a daunting requirement, and with no other preparation than his trademark sparkling wit and alert curiosity.

Abbas had no need of "preparation", since mathematics was his mother tongue-alongside all other languages - and he was breathing it. He used to read scholarly works like mere novels, and handled the most arduous concepts with disconcerting ease. It took him less than 2 years to complete his Ph.D. dissertation, compared to 5 or 6 years for a regular doctoral student. And what a thesis! He revolutionized the study of partial differential equations by summoning the tools of geometry. His encyclopedic culture enabled him 
to free himself from all interdisciplinary boundaries, giving him unrivaled power in analyzing and solving problems.

Upon defending his thesis, he immediately flew back to Tunis-distancing himself from the royal roads laid down in tribute to his genius - to integrate the Faculty of Sciences in 1981 as a senior lecturer. His great ambitions for Tunisia were as short-lived as his plans to elevate the institution to higher standards.

Disillusioned, he packed his bags and was back on the road again. In 1982, he settled in Chicago and then moved back to Paris 'Ecole Polytechnique' before joining Rutgers University in 1987, where he would spend the rest of his career.

In 1990, he crossed paths with an eminent statesman-Mohamed Charfi—Education Minister, who by reinstating him as a professor at the National Engineering School of Tunis, restored the honor and credibility of the Tunisian university. We were able to take full advantage of his skills and influence to launch a Ph.D. program in Applied Mathematics, in which he played a decisive role. Orchestrating the myriad of visits by international experts to Tunis, and those of our own instructors and doctoral students to the U.S., hosting a high-level seminar, supervising numerous doctoral students, and teaching a Master's degree on the latest trends in mathematics, Abbas deployed unrivaled energy to raise that program to the highest international levels. He was constantly available, extremely patient and kind, especially to youngsters, and generous to a fault when it comes to sharing his inexhaustible knowledge and unwaveringly humble.

When political tribulations warded him off the country again, for his freedom of mind could not tolerate any compromise, Abbas continued to sustain collaboration with Tunisian mathematicians. Many of them-young and old - were regularly invited to Rutgers, helping them to forge links with the international community. And numerous were his talks in the most essential, profound and at the same time plain Tunisian mathematical inner sanctums, such as the annual "Dar El Hout" symposium which he constantly enriched with his presence and keen interest. Abbas despised nothing more than glitz, artificial lighting, since he himself was pure shining light.

From that behemoth, my younger brother, I learned more than from many of my masters. First, to never think small, for no ambition can be great enough for our country, should it make science its credo. He firmly believed that a page in history had turned and it was up to us to rebuild the world. God ... was he right!

Farewell Abbas, the friend, the brother. So long, the uncle, so funny and loving, that my children recall so movingly. Goodbye, the living symbol, and all the more alive today in our hearts that you are no more. There, in that distant land where we will meet someday, I know that your equations will live on, your resounding voice continues to startle and your spark to shine. Then, when lightning strikes, when storm roars and a booming laughter rumbles, I know that you will be acting up. And I will be overjoyed to know you are forever close ... for you have not left us, have you?

Mohamed Jaoua Mathematician

Acknowledgements Text of the tribute to Abbas Bahri published in French in January 14th, 2011. The author is deeply grateful to Meriem Chichti and Karim Maghrebi for their invaluable contributions to make this English version a translation far from any betrayal.

Open Access This article is distributed under the terms of the Creative Commons Attribution 4.0 International License (http:// creativecommons.org/licenses/by/4.0/), which permits unrestricted use, distribution, and reproduction in any medium, provided you give appropriate credit to the original author(s) and the source, provide a link to the Creative Commons license, and indicate if changes were made. 